\title{
DEVELOPMENT VERSUS DISPLACEMENT DILEMMA IN WEST BENGAL: UNRAVELING A GANDHIAN SOLUTION
}

\begin{abstract}
The tendency to equate economic growth with industrialization has in the recent past started a violent and bloody movement in the Indian state of West Bengal. The movement that started against forced acquisition of agricultural land for industrialization in Singur gradually spread to other parts of the state of West Bengal including Nandigram. This movement acquired explosive proportions with the intellectuals, civil society and anti-left political parties throwing in their weight behind the displaced peasants who lost their land. Ultimately it became an albatross around the neck of the Left leadership and sunk the political fortunes of the thirty-four year old Left Front government in 2011 state assembly elections. The Singur and Nandigram tragedy are only one among the many agitations that have exploded in various parts of India in recent past. These protest movements have kicked off the development versus displacement debate in India. The killing of protesting peasants in Singur and Nandigram by the trigger happy police not only exposes the political myopia and inhuman indifference of the so-called pro-poor Left Front Government of West Bengal. But it also goes on to show that the political process in India is increasingly getting hijacked by the logic of the market which sees displacement only as an appendix to development. What we need today is to reinvent the principles laid down by Gandhi to usher in a just and equitable economic order. The Gandhian
\end{abstract}

* Department of Political Science, University of Kalyani, India, e-mail:shiladitya_chak@yahoo.co.in 
model of economic development is based on the simple yet profound principles of altruism and egalitarianism. This article would focus on the reasons behind the inception of a violent movement in Singur and Nandigram, the fundamental flaws in the development model of the erstwhile Left Front Government of West Bengal, and end by providing a Gandhian solution to the development versus displacement dilemma in the state of West Bengal in India.

\section{Key words}

Industrialization, Development, Displacement, Panchayat System

\section{Introduction}

More than 50 years ago a debate started amongst the economists of the newly independent developing countries of the world. The moot question was - what was the right course of economic development? Accordingly, economists like Sir William Arthur Lewis suggested economic development through the process of transferring labour from low productivity activity like agriculture to high productivity modern industry. This thought process where the emphasis was on accumulation of physical capital like machinery, buildings, etc. shifted to human capital accumulation in the mid-1980s. Economists like Amatya Sen argued that that investment in education and human capital formation were crucial determinants of the long-term growth and development of an economy. However, neither of the two schools of thought could visualize that 'land' could become a serious constraining factor in the process of economic development especially in third world countries like India. The underlying assumption was that land requirement is negligible for industries and therefore can be safely ignored (Sarkar, 2007).

Scarcity of land, however, has proved to be a serious problem in many third world countries including India where protest movements have erupted against the forcible acquisition of land by the Government for development and industrialization. When land is acquired for the purpose of industrialization, it invariably entails eviction of people from their traditional livelihood and surroundings. The recent experience in the Indian state of West Bengal would testify that this is a matter with grave socio-political consequences, critical enough to disrupt and perhaps even stall the pace of industrialization in India. The purpose of this paper is to analyze the land acquisition and eviction experience of the people of Singur and Nandigram in the Indian state of West Bengal. The paper would 
narrate the events that took place in the two places of Singur and Nandigram to get a grip on the general problem of displacement due to development and industrialization in India. Then the article would try to provide a solution to this moral dilemma of balancing development with displacement based on the principles of Gandhi. The analysis would not only be relevant for India but many more third world countries that are facing a similar moral dilemma of sacrificing the interest of the minority for the happiness of the majority.

\section{Economic Scenario in the State of West Bengal from 1977 to 2000}

In order to understand why there was a violent movement against land acquisition by the Left Front Government in West Bengal we need to delve deeper into the economic scenario prevailing in West Bengal since the late 1970s. The first decade of Left Front rule which began in the year January 1977 in West Bengal marked significant progress in the agricultural sector. The progress was based on three different policy initiatives. First, just after coming to power in 1977, the Left Front government embarked upon a series of far-reaching land reforms in West Bengal. Land reform in West Bengal assumed two forms, 'barga' and 'patta'. The system of 'Barga' gave the share cropper protection against possible eviction from the land he had been cultivating for generations and assured him a fixed share in the crop output. The system of 'Patta' involved redistribution of ownership of excess land acquired from rich landlords (Zamindars) through implementation of land ceilings. Up to the year 2000, 1.6 million 'bargadars' (sharecroppers) had been officially recorded and this was almost 86 per cent of the sharecroppers in the state of West Bengal. In a similar vein 1.39 million acres of land were acquired by the government for redistribution and out of this 1.04 million had been actually redistributed. In fact, West Bengal accounts for 20 per cent of the total land redistribution in the country even though it accounts for only 3.5 per cent of the total land in India. Secondly, the Left Front government introduced a new method of cultivation using high yielding variety of seeds, commonly known as 'Boro' cultivation. The plus point of Boro cultivation is that it can be carried on in small plots of land using a lot of labour. This allowed small and marginal farmers to raise multiple crops with higher yields and played a dominant role in the process of the green revolution in West Bengal. Thirdly, there was a decentralization of rural power through the three-tier 'panchayat system' (system of rural local government). These initiatives, among other things, brought in greater representation and participation of the poor landless laborers and small cultivators in the rural elected bodies called Gram panchayats. Comparing Gram panchayats (rural local governments) in 1978-83 with those in 
1988-93, it is found that representation of 'bargadars' or sharecroppers increased from 1.8 per cent to 11.3 per cent, that of landless labour from 4.8 per cent to 16.8 per cent. This gave the rural poor not only a voice in the decision-making process, but, more importantly, a kind of dignity and social prestige unheard of in the previous political regime. All these factors led to prosperity and growth in rural West Bengal. West Bengal emerged as the largest rice producing state in India contributing more than 15 per cent of national production (Sarkar, 2007).

Unfortunately, agricultural growth significantly slowed down since the 1990s in West Bengal. This was due to a number of reasons. Firstly, there was a complete saturation in new agricultural land that was brought under 'boro' cultivation. Secondly, due to faulty marketing strategies West Bengal failed to export its rice to other states and abroad. Lastly, there was a steep rise in the agricultural input prices, especially that of fertilizers, electricity and diesel. All these factors taken together made cultivation less profitable in West Bengal. As a result, cultivators who accounted for 38 per cent of the rural workforce in 1991 fell to 25.4 per cent in 2001 (Sarkar, 2007).

Against this background the Left front government came back to power for the seventh consecutive time in May 2006 assembly elections in West Bengal under the leadership of Shri Buddhadeb Bhattacharjee. This victory in the assembly election was interpreted by the left leaders as a popular verdict in favour of its industrialization policy. Soon thereafter the Left Front government embarked on its path of industrialization with the slogan of "agriculture is our foundation, industry our future". But very soon it got entangled in a major controversy over the issue of acquisition of agricultural land for setting up industries in West Bengal, especially in the context of the Tata Motors plant in Singur and a proposed chemical hub near Haldia in Nandigram.

\section{The Protest Movement in Singur and Nandigram against Land acquisition}

Singur is a rural block in the Hoogly district of West Bengal approximately $45 \mathrm{~km}$ away from the main city of Kolkata. Nandigram on the other hand is located about $170 \mathrm{~km}$ south-west of the main city of Kolkata, on the south bank of the Haldi River, opposite the industrial city of Haldia. The area falls under the Haldia Development Authority. The Left Front Government of West Bengal announced in May 2006 that they would acquire agricultural land in these two areas to set up the Tata Motors 'Nano' small car factory in Singur and a Mega 
Chemical Hub in Nandigram with help from Indonesian conglomerate the Salim Group.

It was against this background that the Singur movement started when the West Bengal Government forcible acquired 997 acres of one the most fertile agricultural land of Singur through the imposition of the archaic colonial Land Acquisition Act of 1894. Almost the entire local population of Singur depended on agriculture with approximately 15,000 people making their livelihood directly from it. This move by the Government not only threatened the livelihood of the local populace but also created environmental degradation. On November 30, 2006, the government clamped "prohibitory orders" under section 144 of Indian Penal Code in the area so as to fence the 997 acres of acquired agricultural land. The land earmarked for the project was taken control of by the state administration amidst protests and fencing off commenced on December 1, 2006. On December 2, 2006 the Left Front government took brutal action against the protesting farmers of Singur. Some 6,000 policemen, combat force and rapid action force were deployed in the project area. When villagers and members of the Krishi Jami Raksha Committee (KJRC) or Agricultural Land Protection Committee protested, they were baton-charged by the police. Hundreds of poor peasants including women were severely injured. Around 50 villagers, including 18 women were arrested under section 307 (attempt to murder) of the Indian Penal Code (IPC). Among those arrested under Section 307 (attempt to murder) of the IPC were a 75-year old woman and two girls in their early teens. Earlier, the police had baton-charged about 7,000 villagers of Singur, including 2,500 women who were demonstrating peacefully at the Block Development Office at Singur on the midnight of September 25, 2006 against land acquisition (Members Khonj Ekhon Porishod, 2007). The Tata 'Nano' small car project faced massive opposition from displaced farmers. Ultimately, on 3 October, 2008 after much public criticism and bad publicity by the media, Tata officially announced that they had abandoned the Tata Nano small car project in Singur.

However this did not put to an end the woes of an already beleaguered Left Front Government of West Bengal. The issues relating to the right to livelihood, food security or the abject surrender of the Left Front government to the interest of the industrial capitalist class churned the political atmosphere of the state of West Bengal. The Singur movement catalyzed the building up of a united opposition against all similar development projects across the state from Nandigram and Haripur in Midnapore district to Bhangar and Baruipur in the North 24 Parganas district of West Bengal. But among them, the one to draw international media attention was the violent peasant movement which started in Nandigram 
in 2007. The Nandigram movement started on $2^{\text {nd }}$ January 2007, when a notice was officially issued by Haldia Development Authority (HAD) that about 14,500 acres of agricultural land would be acquired from the peasants of Nandigram block. Since then, people of the affected villages of Nandigram block started a violent protest movement opposing such despotic acquisition of their agricultural and homestead land. They formed two independent people's organisations named "Gana Unnayan and Jana Adhikar Sangram Samity" (Association for Mass Development and People's Rights) and "Krishi Jami O Janaswartha Raksha Committee" (Committee for Protection of Agricultural Lands and Public Interest) to protect their life and livelihoods (Das, 2007). The villagers of Nandiram responded against the Government by damaging all the roads and bridges to prevent the police force from entering the villages of Nandigram block. The villagers also blocked the roads with boulders and tree trunks. They did not allow police nor the cadre of the ruling Communist Party of India (Marxist) [CPI (M)] party to enter Nandigram for over three months.

Finally on March 14, 2007 the West Bengal Government responded by deploying a huge police and paramilitary force against the protesting peasants to forcibly capture Nandigram. In the name of removing blockades and restoring "normalcy" what followed was atrocious manhandling, assault and straightforward violation of human rights of the people by not only the state government police and para-military forces but also the cadres of the ruling political party -

Communist Party of India (Marxist) [CPI(M)]. The CPI (M) party's cadre allegedly bolstered by the police action against the peasants of Nandigram, hired hardened criminals from within the state and outside, conducted a joint operation along with the state government police on the protesting peasants. Teargas shells were burst and rubber bullets fired at the villagers, mainly women and innocent children. The eyewitnesses to the massacre reported that gangs of hooligans of CPI (M) party dressed in police uniforms threw bombs and fired many gunshots at villagers. Houses and shops were ransacked by the offenders. The police also opened fire using live ammunition. The police unleashed a reign of terror, killing at least 14 people, maiming many more. Besides the fatalities, at least 75 people were injured - among them a dozen policemen (The Telegraph, 2007). The killings drew widespread condemnation, including a grim statement from Governor of West Bengal Gopal Krishna Gandhi that - "the news has filled me with a sense of cold horror". "What is the public purpose served by the use of force that we have witnessed today" (Zee News, 2007).

The horrific police atrocities on the people of Nandigram were also condemned by the honourable High Court at Calcutta, when, on 15 November 2007, 
a Division Bench declared that the action of the police department to open fire at Nandigram on 14 March 2007 was wholly unconstitutional and could not be justified under any provision of the law. Rejecting all the arguments put forward by the state government, the High Court directed the state government to pay a compensation to the next of kin of those killed in police firing or for those raped and injured in the firing. The court also directed the Central Bureau of Investigation (CBI) to start criminal proceedings against those responsible for the firing and the violence (Sarkar, 2007). After the bloodshed at Nandigram and the stiff resistance from opposition parties, Chief Minister Buddhadeb Bhattacharjee finally on 3 September, 2007 expressed the government's preference for the sparsely populated island of Nayachar, 30 kilometres from Haldia, to set up the much talked-about chemical hub (The Times of India, 2007).

\section{Gandhian solution to the Problem of Displacement due to Development}

But the question that intrigues social scientists is - why did the people of Singur and Nandigram protest against government acquisition of agricultural land despite cultivation being less profitable in West Bengal? Perhaps the answer to this entire controversy can be found in prescriptions of Mahatma Gandhian who really understood the heart and soul of India. Gandhi had once observed - "Industrialism is, I am afraid, going to be a curse for mankind" (Singh, 1988). Gandhi felt industrialism lead to the destruction of rural areas, created iniquitous distribution of national wealth, automation leading to large scale unemployment and finally formed the basis of imperialistic exploitation of one nation by another. All these observations of Gandhi hold true in case of Singur and Nandigram. It can probably be said that the land acquisition for industrialization is not only a complete reversal of land reforms brought about by the Left Front government in the 1970s but is has lead to a loss of livelihood of the poor people in the state of West Bengal.

For Gandhi the end to be sought was human happiness combined with full mental and moral growth. This end could be achieved only under decentralization. Centralization as a system was inconsistent with the non-violent structure of society as envisioned by Gandhi (Brown, 1969). In this land acquisition drive, the decentralization process was reversed in West Bengal. For Gandhi "Independence must begin at the bottom. Thus every village will be a republic or Panchayat having full powers." Gandhi believed that Panchayat raj (village 
republics) was "true democracy" and was not to be endowed from the state at the top downward to the people, but to be gained by the people from bottom (Kazuya, 2001). Thus the PRIs were introduced with the avowed aim to strengthen grass-root democracy and initiate rural development with the participation of rural communities from the stage of planning itself. But the industrialization programmes in rural areas were planned by surpassing even the highest tier of the PRIs in West Bengal. The PRIs were just turned into agencies to implement these programmes. No discussion ever took place in the gram sansad meetings in the panchayats where the land acquisition drive took place. Thus, the land acquisition drives of the Left Front government implied complete denial of the right of the rural people to decide their own fate, which presumably was the main cause behind the peasant unrest in both Singur and Nandigram. Further, this was also a denial of their right to livelihood and access to food since the rural poor mostly survive on subsistence farming. Losing land means losing minimum security of livelihood they have (Banerje \& Roy, 2007).

The principal debating point that both these movements raise is whether this industrialization would benefit the vast masses of the rural poor who are being asked to make sacrifices for the sake of "development"? Gandhi had said in this regard that "At present the machine is helping a small minority to live on the exploitation of the masses." Gandhi believed that the motive force of this minority was "not humanity and love of their kind but greed and avarice." He believed that - "Machinery is the chief symbol of modern civilization, it represents a great sin" (Kazuya, 2001). All these observations of Gandhi have become prophetic today. Although there had been a steady rise of investment in West Bengal, there has been a steady decline in employment generation in West Bengal between 1990-91 to 2001-02. During the period 1990-91 to 2001-02, though the number of industries in West Bengal increased from 5,606 to 6,195 and invested capital from Rs 12,517.67 million to Rs 32,752.98 million, the number of employees in these industries have declined significantly from $7,40,980$ to $5,45,447$. Thus employment generation in the upcoming industries in recent times is minimal, confirming the fear of "jobless growth". The highly mechanized large industries can accommodate only a few of the poor unskilled people. With industries depending on a capital-intensive approach to survive in competition, only a section of the educated youth, that too mostly urban, can find employment in them. The rural poor with little formal education would hardly find a place in these upcoming industries while they suffer the most in the land acquisition drive (Banerjee \& Roy, 2007). 
In the age of globalization we are experiencing a paradox in the process of development. On the one hand India has witnessed an average growth rate of around seven percent since 1997, and on the other there is no denying the fact that the intensity of deprivation, oppression and exploitation of the underprivileged has increased despite this high economic growth. Development policies have not only failed to benefit the marginalized and deprived sections in rural areas, but have also increasingly threatened their sources of livelihood. In this context the much neglected viewpoints of Gandhi hold true today. Gandhi regarded materialism to be the main feature of modern western civilization in which spirituality seemed to be undervalued. Gandhi made a distinction between economic progress and real progress. He observed that real progress hinged on the moral progress of society while economic progress focused only on the material advancement of society. Gandhi reiterated that man in a modern civilization was enslaved by temptation of money and of the luxuries that money could buy for them. Gandhi therefore observed -"It is my deliberate opinion that India is being ground down not under the English heel but under that of modern civilization." Gandhi firmly believed that civilization consisted not in multiplication, but in the deliberate and voluntary reduction of wants (Kazuya, 2001). What we are witnessing today is not real progress but a mindless economic development based on greed and avarice which is being facilitated by the philosophy of economic liberalization and global free trade.

If we want to usher in true development, then we should seriously operationalize the Gandhian scheme of constructive programme and planning in India. We should not forget that the fundamental idea that economic development is only a means to an end and not an end in itself. The top priorities of planning in rural India should be towards (i) agricultural development, (ii) development of labour intensive small scale village industries, (iii) promotion of housing, health, and cleanliness of the village people, (iv) spread of education in villages, and (v) encouragement to cultural development of villages. This perspective on development has been very consciously rejected by the Indian planners and authorities due to whom we are facing the recurrent problems of displacement of rural poor in many parts of India including Nandigram.

\section{Conclusion}

Today, India has deviated from the paths Gandhi indicated. For Gandhi the overriding necessity was not such economic growth, but non-violence. Only two life principles govern all Gandhi's economic, social, political and other 
considerations, viz. "Truth and Non-violence". Anything that cannot be satisfactorily tested on these touch-stones, as it were, cannot be regarded as Gandhian. If a scheme of things leads to violence or necessitates untruth, then we may regard that as non-Gandhian (Kumarappa, 2007). Gandhi was not against large-scale industries. However, what he wanted was to sterilize it by taking away the profit motive, substituting for it only the service motive. Gandhi wanted to remove the chances of the wealthier or the more talented people exploiting the masses, and that is what we need today (Kumarappa, 2007). Thus a non-violent socioeconomic order based on Gandhian principles is the panacea to the dilemma of development versus displacement in India. To build this what is required is adequate amount of political decentralization followed by need based bottom-up economic development. Indian culture consists in unity in diversity which cannot be preserved without a sense of decentralization and local autonomy.

\section{REFERENCES}

Banerjee, P. S., \& Roy, D. (2007). Behind the Present Peasant Unrest in West Bengal. Economic and Political Weekly, 42(22), pp. 2048-2050.

Brown, J.M. (1969). The Mahatma and Modern India, Modern Asian Studies, 3(4), pp. 321-342.

Das, A. (2007). People's Uprising against Forced Land Acquisition: All Disquiet on the Nandigram Front, Paschimbanga Khet Majoor Samity. Retrieved from http://khetmajoorsamity.blogspot.in/2011/05/all-disquiet-on-nandigram-front.html.

Kazuya, I. (2001). The socio economic thoughts of Mahatma Gandhi: As an origin of Alternative Development. Review of Social Economy, 59(3), pp. 297-312.

Kumarappa, J.C. (2007). Gandhian Economic Thought, Sarva Seva Sangh Prakashan, Rajghat, Varanasi: 5. Retrieved from http://www.mkgandhi.org/ebks/GandhianEconomic-Thought.pdf.

Members Khonj Ekhon Porishod (2007). Women's Protests in Singur. Economic and Political Weekly, 41(52), p. 5290.

Sarkar, A. (2007). Development and Displacement - Land Acquisition in West Bengal. Economic and Political Weekly, 42(16), pp. 1435-1442.

Sarkar, Sh. (2007). Calcutta HC pulls up state over March firing in Nandigram, Meri News- Power to People. Retrieved from http://www.merinews.com/article/calcuttahc-pulls-up-state-over-march-firing-in-nandigram/127790.shtml\#sthash.QsuVpfNU.dpuf.

Singh, R. (1998). Gandhi and the Modern World. New Delhi: Classical Publishing Company.

The Telegraph (2007). Red-hand Buddha 14 killed in Nandigram re-entry bid. Retrieved from http://www.telegraphindia.com/1070315/asp/frontpage/story_7519166.asp. 
The Times of India. (2007). Nandigram's chemical hub shifted to Nayachar. Retrieved from http://timesofindia.indiatimes.com/India/Nandigrams_chemical_hub_shifted_to_Nayachar/rssarticleshow/2335936.cms.

Zee News. (2007). Governor expresses 'cold horror' at Nandigram violence. Retrieved from http://zeenews.india.com/home/governor-expresses-cold-horror-at-nandigramviolence_360076.html. 